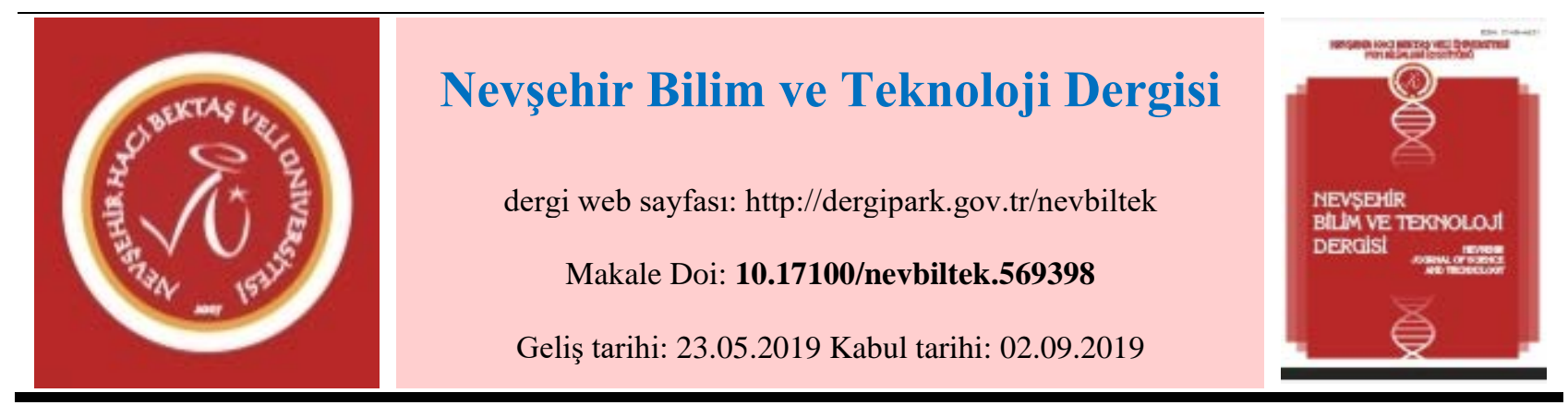

\title{
Erzurum Kentindeki Bazı Önemli Parkların Peyzaj Kalite Göstergelerinin Değerlendirilmesi ${ }^{1}$
}

\author{
Ayşe KARAHAN ${ }^{1}$, Iş1k SEZEN ${ }^{2}$ \\ ${ }^{1}$ Atatürk Üniversitesi, Mimarlı ve Tasarım Fakültesi, Peyzaj Mimarlı̆̆ı Bölümü, Erzurum \\ ORCID ID:0000-0001-6256-1370 \\ ${ }^{2}$ Atatürk Üniversitesi, Mimarlı ve Tasarım Fakültesi, Peyzaj Mimarlığı Bölümü, Erzurum \\ ORCID ID:0000-0003-0304-9072
}

Öz

Kentsel yeşil alanların önemli bileşenlerinden birisi parklardır. Parkların daha fonksiyonel ve estetik olması için peyzaj kalite göstergeleri dikkate alınarak tasarlanmaları gerekmektedir. Bir parkın erişilebilirliği, bitkisel tasarımı, güvenilirliği, sahip olduğu donatı elemanlarının zenginliği ve kalitesi gibi birçok özelliği kullanıcılar tarafından daha fazla tercih edilir olmasını sağlamaktadır. Kent parklarındaki peyzaj kalite göstergelerini değerlendirmek amacı ile gerçekleştirilen bu araştırmanın materyalini; Erzurum kentinde yer alan önemli parklardan Olimpiyat Parkı, 100. Parkı, Tavşanlı Park, Recep Tayyip Erdoğan Parkı, Millet Bahçesi, Şehitler Parkı, Palandöken Aile Çay Bahçesi oluşturmaktadır. Araştırma alanını oluşturan parklarda video ve fotoğraf çekimi yapılarak 20 kişiden oluşan uzman gruba foto-video anket uygulanarak görsel etki, yapısal tasarım, bitkisel tasarım, döşeme kalitesi gibi peyzaj kalite göstergelerinin 5'li Likert Ölçeği ile değerlendirmeleri sağlanacaktır. Araştırmanın sonucunda; Erzurum kentinde yer alan en yoğun olarak kullanılan 7 parkın peyzaj kalite göstergeleri değerlendirilerek yeterli ve yetersiz yönleri belirlenecek, önerilerde bulunulacaktır.

Anahtar Kelimeler: Kent, park, peyzaj, kalite göstergesi

\section{Evaluation of Landscape Quality Indicators of Some Important Parks in Erzurum City}

\begin{abstract}
One of the important components of urban green areas is the parks. In order for the parks to be more functional and aesthetic, they should be designed considering the landscape quality indicators. Many features such as the accessibility, vegetative design, reliability, richness and quality of the reinforcement elements of a park make it more preferred by users. The aim of this research is to evaluate the landscape quality indicators in urban parks; Olympic Park, 100th Park, Tavsanli Park, Recep Tayyip Erdogan Park, National Garden, Martyrs' Park, Palandoken Family Tea Garden are among the important parks in Erzurum. In the parks which constitute the research area, photograph and video survey was applied to the expert group consisting of 20 people, and landscape quality indicators such as visual impact, structural design, plant design, floor quality were evaluated with 5point Likert Scale. As a result of the research; the landscaping quality indicators of the 7 most commonly used parks in Erzurum city were evaluated by landscape architects with a postgraduate degree (master and / or doctorate) and their adequate and inadequate aspects were determined and recommendations were made.
\end{abstract}

Keywords: Urban park, landscape design and application, landscape quality indicators, Erzurum

\footnotetext{
${ }^{1}$ 22-24 Nisan 2019 tarihinde Marmaris'de gerçekleştirilen II. Uluslararası Mühendislik ve Mimalık Kongresi (ENAR-2019)’nde bildiri olarak sunulmuştur.

Sorumlu yazar e-mail: isiksezen@atauni.edu.tr
} 


\section{Giriş}

Kent yaşamı insanlar üzerinde toplumsal, sosyolojik, ekonomik ve psikolojik baskılar oluşturmaktadır. Kentsel mekanlar yapısal yoğunluk, trafik yükü, kirlilik vb. faktörlerin baskısı altındadır. Kentlerde var olan yeşil alanlar, kentte yaşamanın getirdiği olumsuz koşulları iyileştirici etkiye sahiptir. Kentin yaşam kalitesinin artırılmasında kent parklarının rolü büyüktür. Kent parklarının kalitesi ise planlama, tasarım, uygulama, bakım koşullarının başarısına bağlıdır [1].

Kent parkları üzerine yapılmış birçok araştırma bulunmaktadır. Bu araştırmalar arasında; kent parkı kavramı [2], sürdürülebilir şehirlerde kent parklerının rolü [3], açık yeşil alan olarak parkların kentsel yaşam kalitesi üzerine etkisi [4], kent parklarının görsel peyzaj algısı [5], parkların tasarım kriterleri [6], parklardaki donatı elemanlarının kişisel mekan uzaklığına etkisi [7], ekolojik tasarım kriterlerine göre kent parkı iyileştirme [8], kent parklarının kullanıcı tercihleri [9], parkların mevcut durum değerlendirmesi ve tasarım önerileri [10], kent parklarına yapılan rekreasyonel ziyaretleri etkileyen faktörler [11], kent parkı kullanıcılarının tercihleri ve demografik özellikleri [12] arasındaki ilişki yer almaktadır.

Kent parklarındaki peyzaj kalite göstergelerini değerlendirmek amacı ile gerçekleştirilen bu araştırmada Erzurum kenti örneğindeki önemli parklar ele alınmıştır.

\section{Materyal ve Metot}

Araştırmanın materyalini; Erzurum kentinde yer alan önemli parklardan Olimpiyat Park1, 100. Parkı, Tavşanlı Park, Recep Tayyip Erdoğan Parkı, Millet Bahçesi, Şehitler Parkı, Palandöken Aile Çay Bahçesi oluşturmaktadır. Araştırma alanını oluşturan parklarda video ve fotoğraf çekimi yapılarak 20 kişiden oluşan uzman gruba foto-video anket uygulanarak görsel etki, yapısal tasarım, bitkisel tasarım, döşeme kalitesi gibi peyzaj kalite göstergelerinin 5'li Likert Ölçeği ile değerlendirmeleri yapılmıştır. Kalite kriterlerinin belirlenmesinde; [13-17]'nin kent parkları üzerine yaptıkları araştırmalardan yararlanılmıştır. Erzurum kentinde yer alan en yoğun olarak kullanılan 7 parkın peyzaj kalite göstergeleri lisansüstü eğitim derecesine sahip (yüksek lisans ve/veya doktora) peyzaj mimarları tarafından değerlendirilmiştir. Araştırma materyalini oluşturan parkların kent içindeki konumları Şekil 1'de verilmiş̧ir.

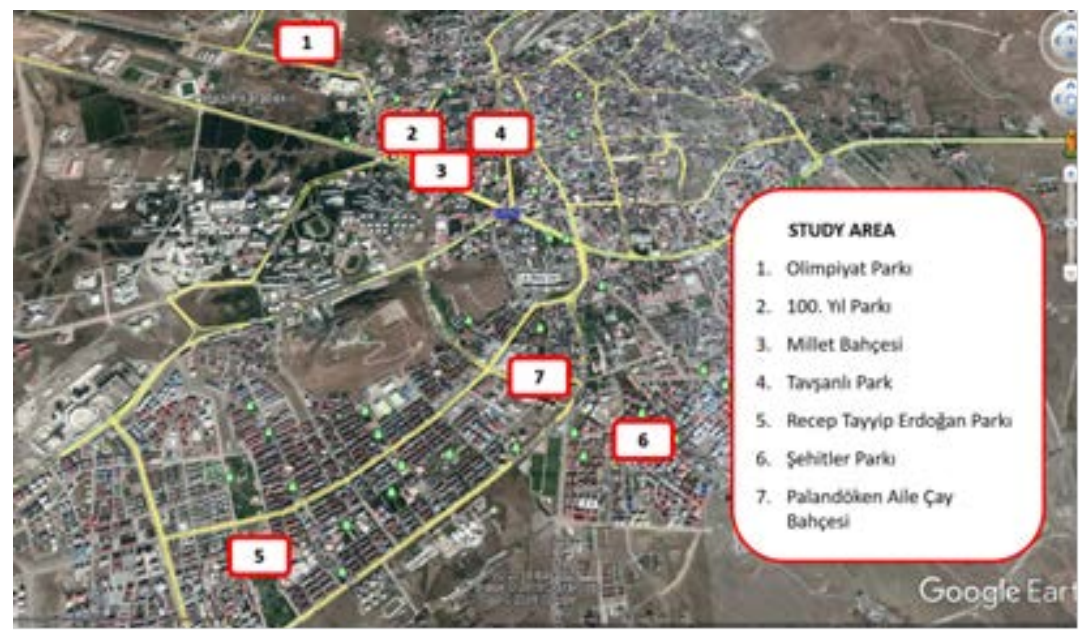

Şekil 1. Parkların kent içindeki konumları 


\section{Bulgular}

Parkların kalite değerlendirilmesinde kullanılan peyzaj kalite göstergeleri Tablo 1'de verilmiştir. Araştırma alanını oluşturan parklarda (Olimpiyat Parkı, 100. Parkı, Tavşanlı Park, Recep Tayyip Erdoğan Parkı, Millet Bahçesi, Şehitler Parkı, Palandöken Aile Çay Bahçesi) video ve fotoğraf çekimi yapılmış 20 kişiden oluşan uzman gruba fotovideo anket uygulanmış görsel etki, yapısal tasarım, bitkisel tasarım, döşeme kalitesi gibi peyzaj kalite göstergelerinin 5'li Likert Ölçeği (1: çok yetersiz, 2: yetersiz, 3: orta seviye, 4: yeterli, 5: çok yeterli) ile değerlendirmeleri sağlanmıştır.

Her bir parktan çekilen ve değerlendirmeye alınan fotoğraflar ve uydu göeüntüleri Şekil 2-8'de verilmiştir.

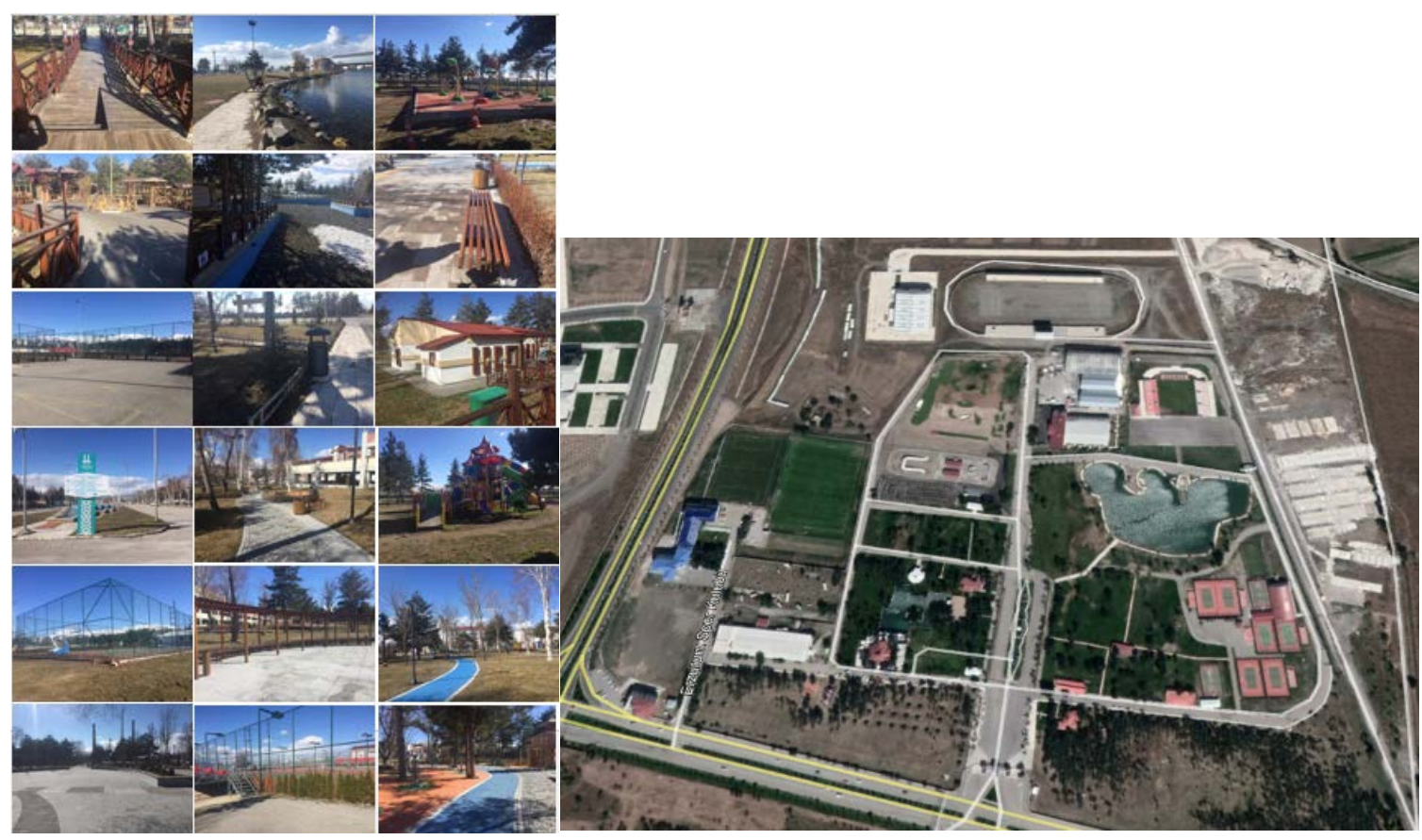

Şekil 2. Olimpiyat Parkı

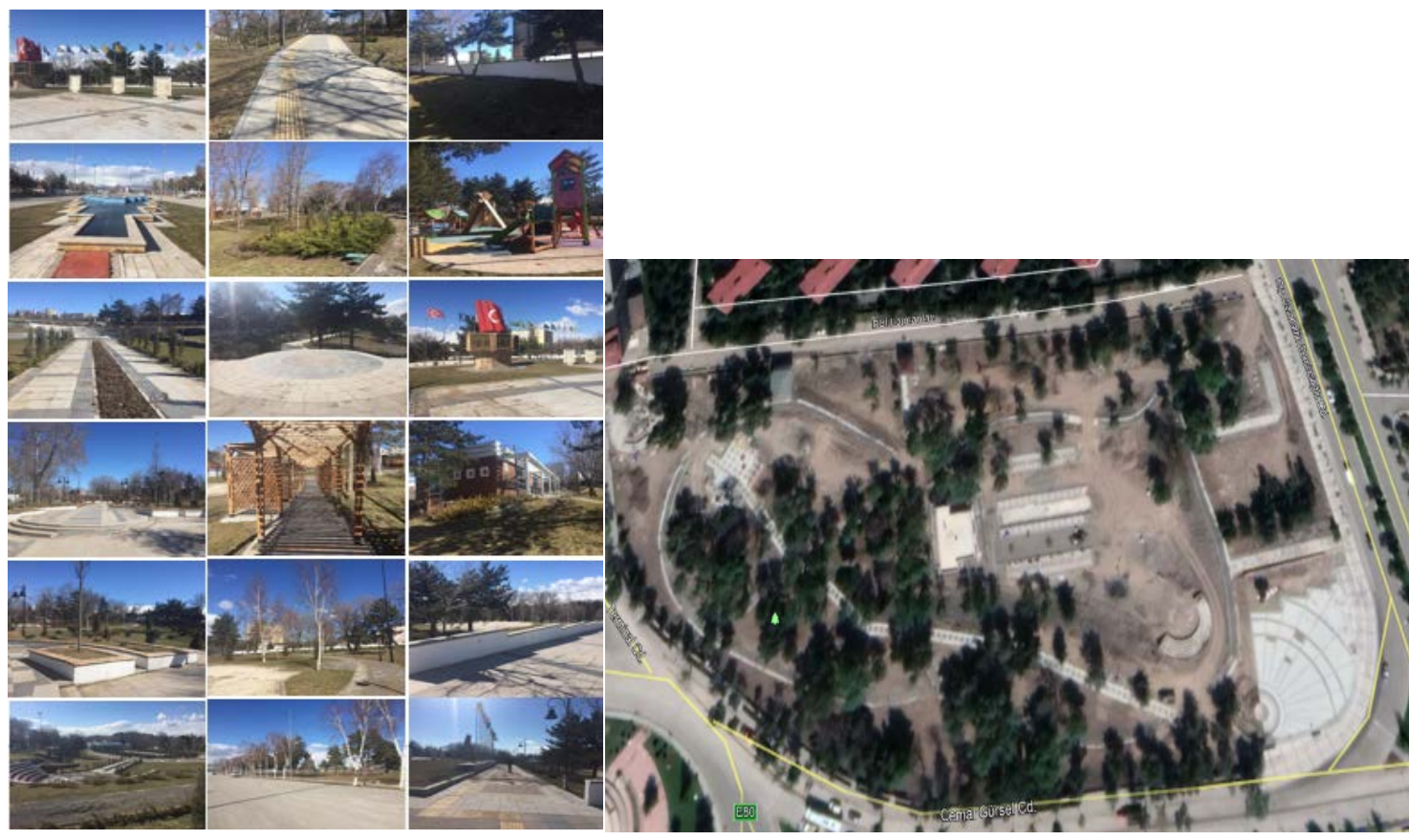

Sekil 3. 100. Y11 Park1 
Nevşehir Bilim ve Teknoloji Dergisi (2019), 8(Enar Özel Sayı) 54-63

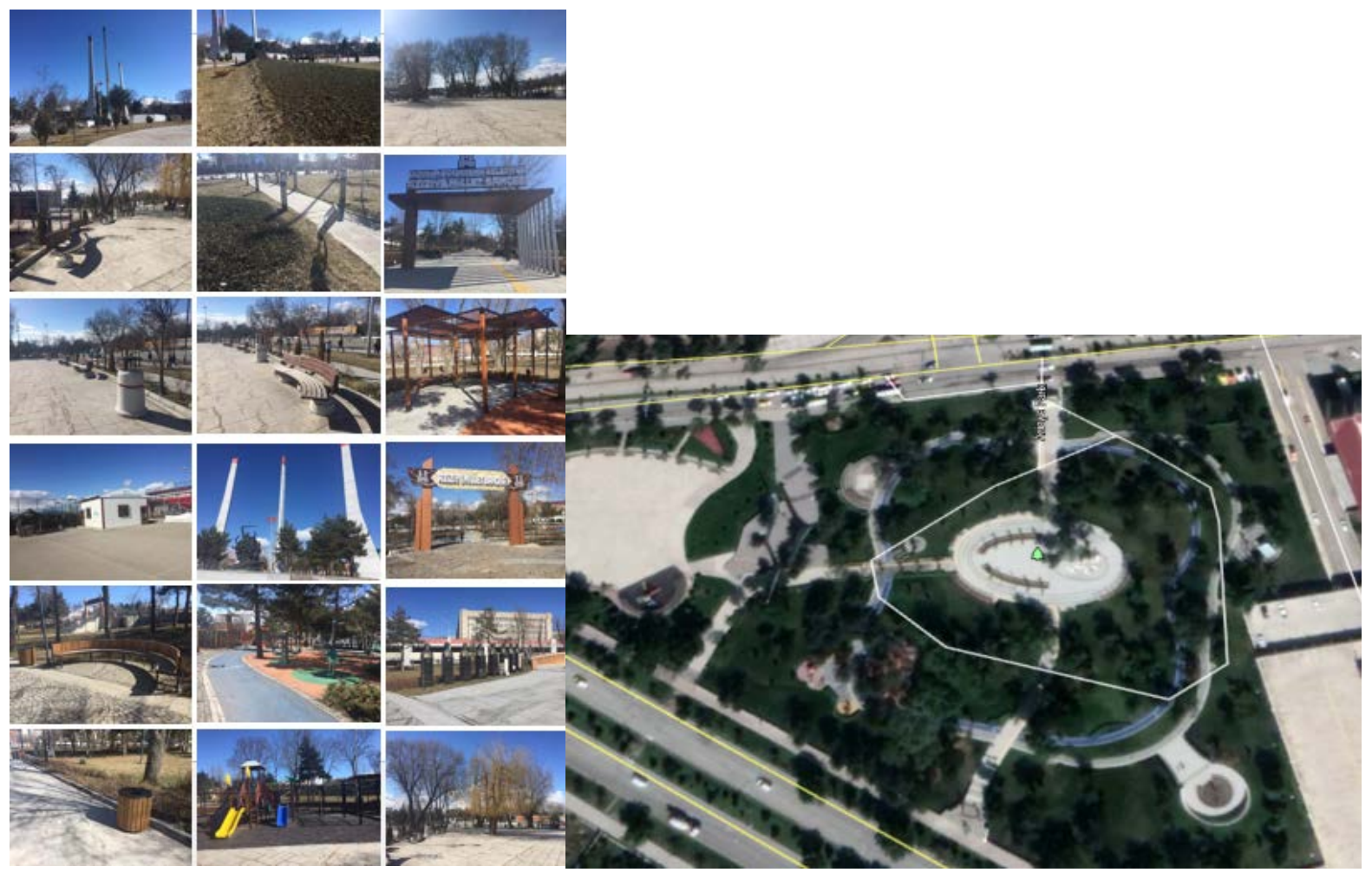

Şekil 4. Millet Bahçesi

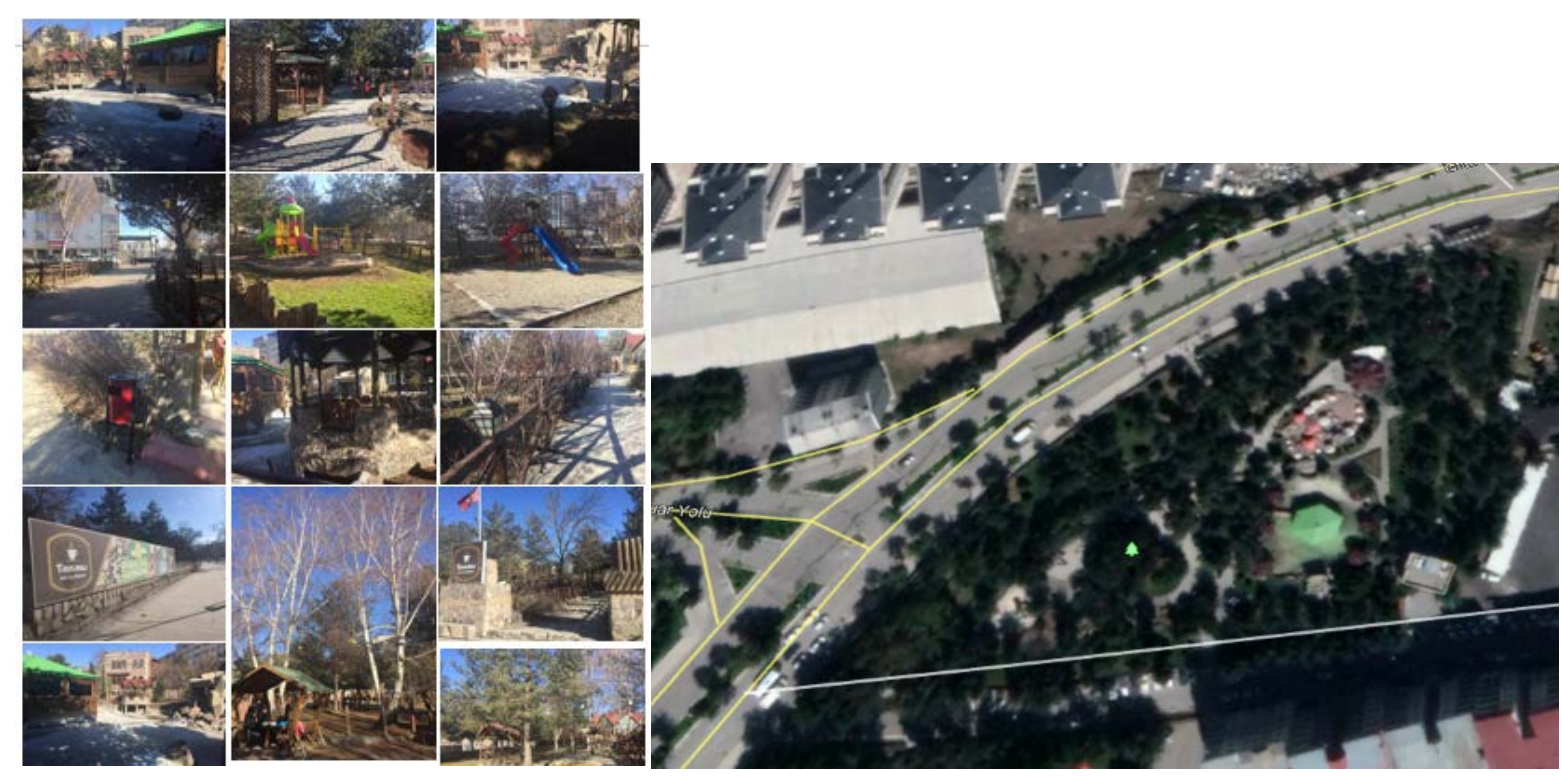

Şekil 5. Tavşanlı Park 
Nevşehir Bilim ve Teknoloji Dergisi (2019), 8(Enar Özel Sayı) 54-63

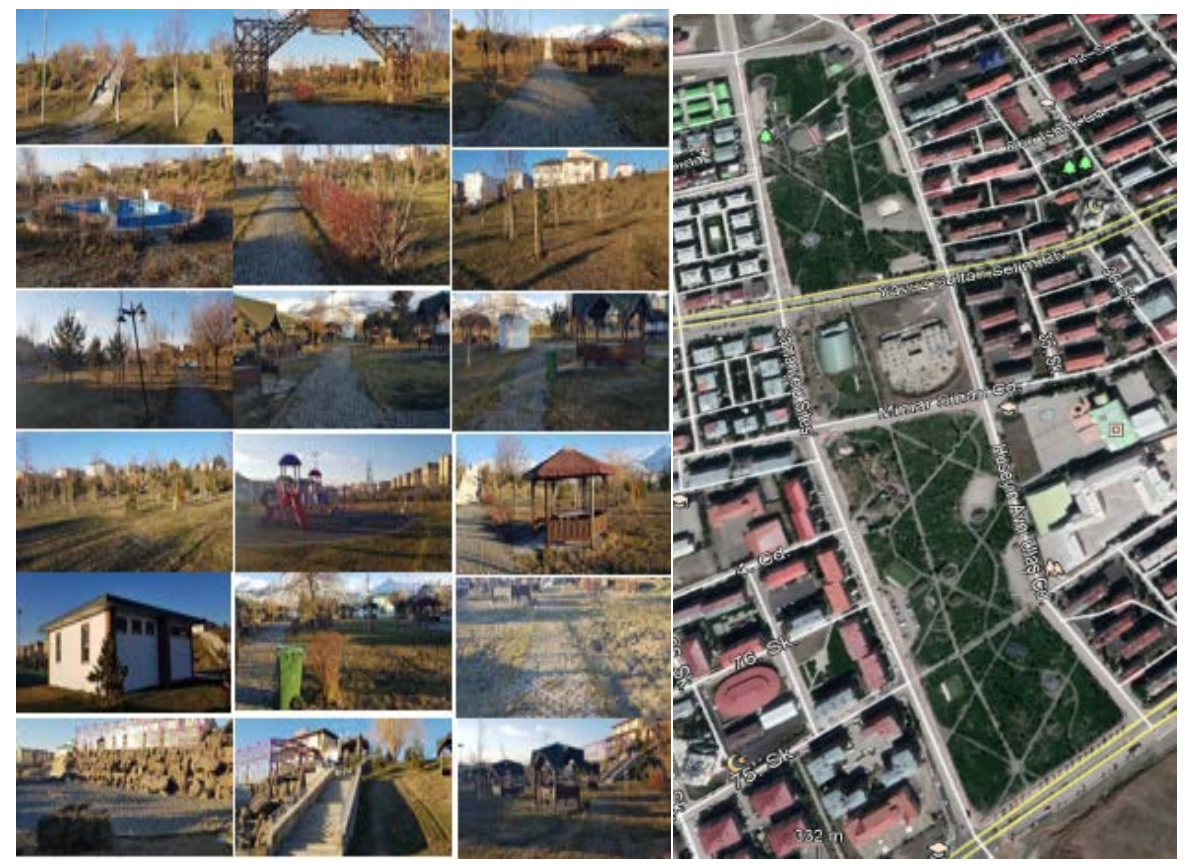

Şekil 6. Recep Tayyip Erdoğan Parkı

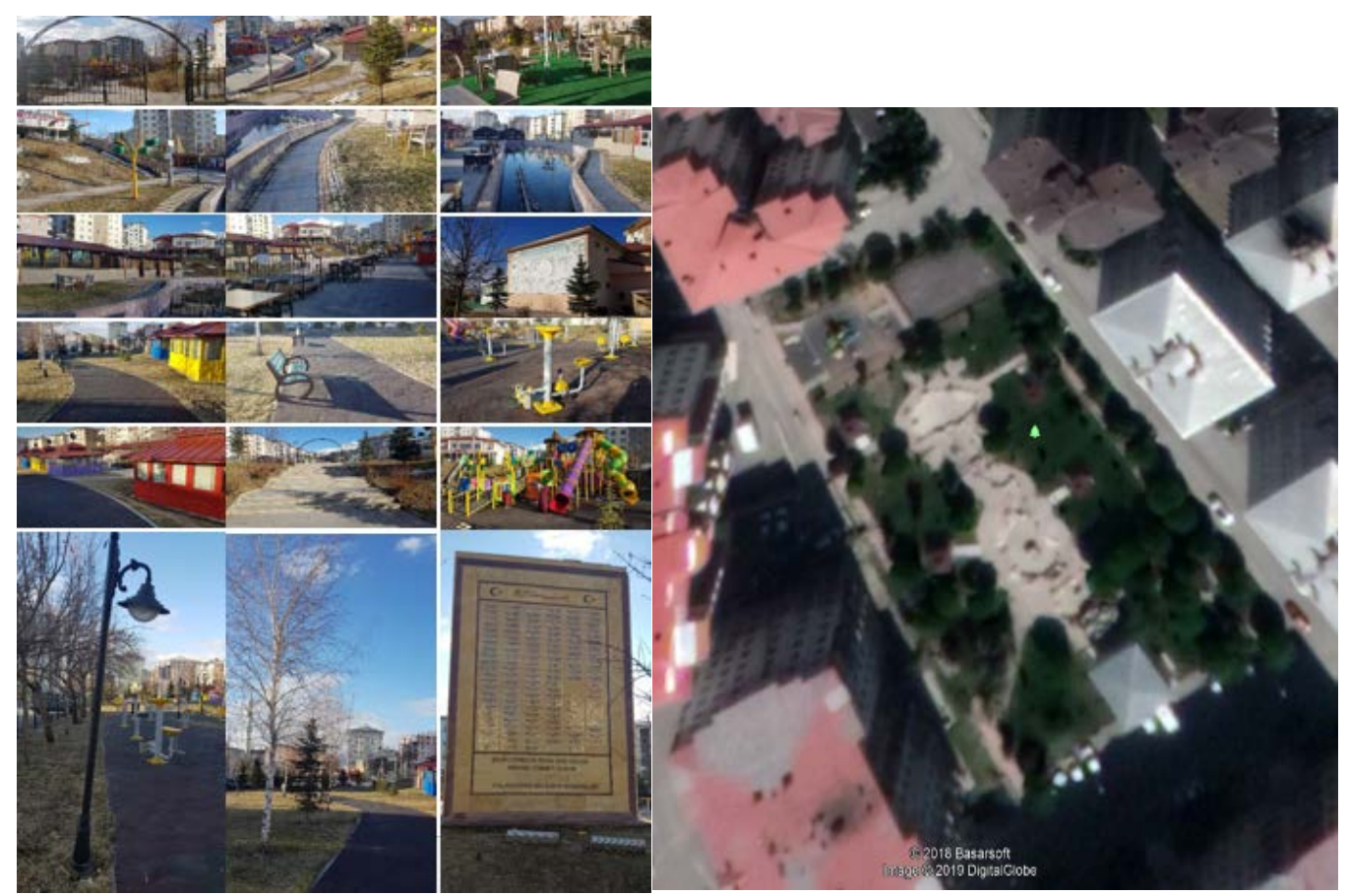

Şekil 7. Şehitler Park1 


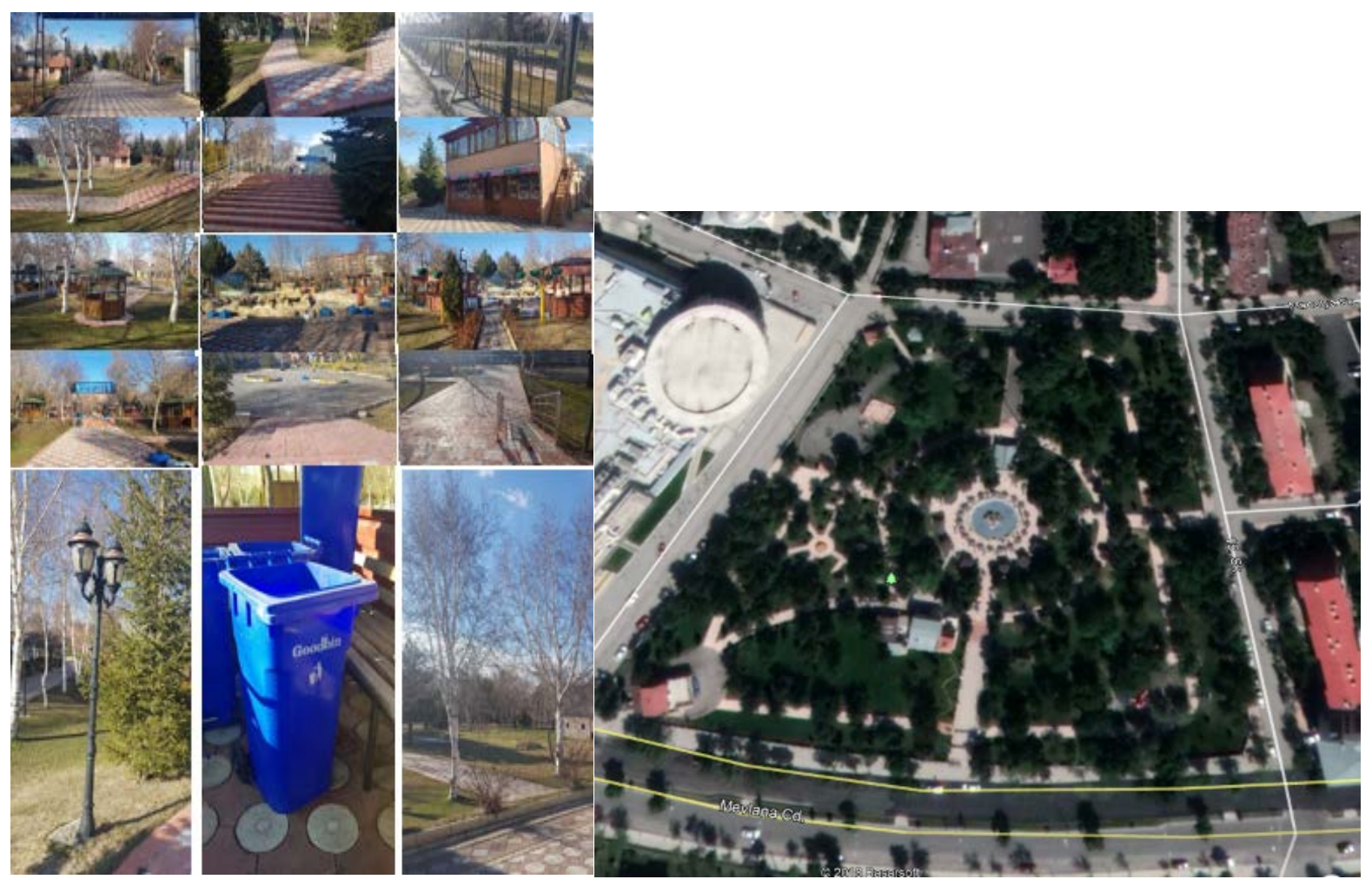

Şekil 8. Palandöken Aile Çay Bahçesi

Uzman peyzaj mimarı grubunun değerlendirme sonuçları Tablo 1'de verilmiştir.

Tablo 1. Uzman peyzaj mimarı grubu değerlendirmeleri

\begin{tabular}{|c|c|c|c|c|c|c|c|c|}
\hline Peyzaj Kalite Göstergeleri & 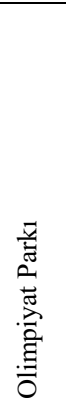 & 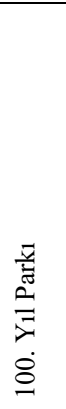 & 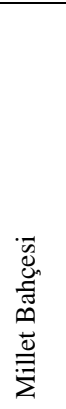 & 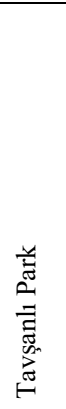 & 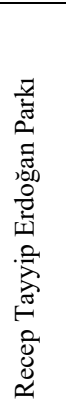 & 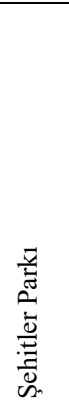 & 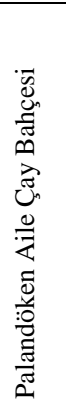 & 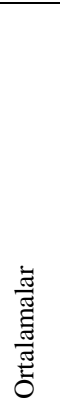 \\
\hline Parkın Görsel Etkisi & 3,50 & 3,10 & 3,70 & 3,50 & 2,00 & 2,70 & 3,60 & 3,18 \\
\hline Parkın Yapısal Tasarımı & 3,50 & 3,30 & 4,00 & 3,30 & 2,10 & 3,40 & 3,70 & 3,33 \\
\hline Kapalı mekan varlı̆̆ 1 & 3,80 & 3,00 & 1,20 & 3,60 & 2,50 & 3,30 & 3,60 & 3,00 \\
\hline Bitkisel Tasarım & 3,40 & 4,00 & 3,60 & 3,00 & 2,20 & 2,80 & 3,60 & 3,23 \\
\hline Havuz, yapay göl gibi su etkisi & 3,60 & 2,80 & 1,50 & 3,00 & 2,10 & 2,80 & 3,30 & 2,73 \\
\hline Çocuk oyun alanı yeterliliği ve kalitesi & 2,90 & 1,60 & 3,60 & 3,00 & 2,50 & 4,00 & 3,10 & 2,96 \\
\hline Giriş kapısı etkisi & 4,20 & 2,60 & 4,00 & 2,20 & 2,00 & 2,00 & 2,50 & 2,79 \\
\hline Çim alanları & 3,50 & 3,20 & 4,00 & 2,90 & 2,60 & 2,80 & 3,70 & 2,24 \\
\hline Donatı elemanları & 3,70 & 3,20 & 4,10 & 3,60 & 2,50 & 3,00 & 3,30 & 3,34 \\
\hline Parkta odak noktası varlığ1 & 3,40 & 2,90 & 3,60 & 2,90 & 2,10 & 2,70 & 2,90 & 2,93 \\
\hline Parka kimlik kazandıracak nitelik & 2,80 & 3,20 & 3,80 & 3,60 & 2,60 & 2,90 & 2,90 & 3,11 \\
\hline
\end{tabular}


Nevşehir Bilim ve Teknoloji Dergisi (2019), 8(Enar Özel Sayı) 54-63

\begin{tabular}{|l|l|l|l|l|l|l|l|l|}
\hline Mekanın güvenlik hissi & 3,60 & 2,90 & 3,60 & 3,40 & 1,80 & 3,20 & 3,20 & 3,10 \\
\hline Ulaşılabilirlik & 3,60 & 4,40 & 4,60 & 4,50 & 3,60 & 3,60 & 4,10 & 4,06 \\
\hline Engelliler için tasarım & 3,20 & 2,90 & 3,80 & 2,00 & 2,00 & 2,30 & 2,50 & 2,67 \\
\hline Parkın bakımı ve temizliği & 4,10 & 3,70 & 4,60 & 3,70 & 2,10 & 4,00 & 3,90 & 3,73 \\
\hline Park içi yaya yolları & 3,90 & 3,90 & 4,00 & 3,00 & 2,80 & 3,10 & 3,60 & 3,47 \\
\hline Park içinde toplanma noktaları & 3,90 & 3,80 & 4,20 & 2,50 & 2,40 & 2,50 & 3,10 & 3,20 \\
\hline Bisiklet yolu uygunluğu & 3,10 & 2,20 & 3,60 & 1,80 & 1,90 & 1,90 & 1,90 & 2,34 \\
\hline Parkın farklı aktivite olanakları & 4,60 & 2,50 & 2,80 & 2,50 & 2,30 & 2,70 & 2,70 & 2,87 \\
\hline Gölgelenmiş mekan varlı̆̆1 & 3,20 & 1,90 & 1,30 & 3,40 & 2,20 & 2,80 & 3,00 & 2,54 \\
\hline Ortalamalar & 3,58 & 3,06 & 3,48 & 3,07 & 2,32 & 2,93 & 3,21 & 3,09 \\
\hline
\end{tabular}

\section{Tartış̧ma ve Sonuç}

Erzurum kentindeki bazı önemli parkların peyzaj kalite göstergelerinin belirlenmesi amacı ile gerçekleştirilen bu araştırmada uzman değerlendirmesine göre; en yüksek kaliteye Olimpiyat Parkı'nın sahip olduğu görülmüş̧ür. Olimpiyat Parkı'nın kalitesini etkileyen en önemli gösterge ise farklı aktivite olanaklarına sahip olması şeklinde değerlendirilmiştir. Olimpiyat Parkı, Erzurum halkının yaz döneminde yoğun olarak talep gösterdiği her yaş grubuna hitap eden fonksiyonları ile ön plana çıkmıştır. Piknik alanları, spor alanları, çocuk oyun alanları, suya dayalı rekreasyon olanakları, kafe, kapalı sosyal tesisler, gezinti yolları, bisiklet yolları, düğün salonu gibi birçok aktiviteyi içeren çok geniş bir alana kurulmuş bir parktır. Bu tür aktivite alanlarının yoğunluğu parka gelen kullanıcıların daha fazla sosyalleşmesini sağlamaktadır. Nitekim [4]'ün de belirttiği gibi park alanlarının kent içinde "yeşil" sistemi oluşturma özelliği olduğu gibi bu sistemin devamlılığı için sosyal bir mekan olma özelliğine de sahip olmaları gerekmektedir.

İkinci sırayı alan Millet Bahçesi uzman görüşlerine göre; ulaşılabilirlik, parkın bakım ve temizliği kalite göstergeleri ile ön plana çıkmıştır. Erzurum Büyükşehir Belediyesi tarafından Aziziye Anıtı'nın bulunduğu yerde gerçekleştirilmiş park, henüz çok yeni olan peyzaj tasarımıyla dikkat çekmektedir. Bisiklet ve yürüme yolları, oturma alanları, oyun parkı, dev satranç alanı ile mini süs havuzu, engelli tasarımına uygunluğu ile tercih edilmektedir. Aziziye Anıtı parka kimlik kazandırmıştır. Aziziye anıtı Erzurum kenti tarihini anlatan bir yapıttır. [17]'nin de belittiği gibi kent kimliğini oluşturan bileşenlerden birisi de tarihi değerlerdir.

Araştırma sonucunda en düşük kalite standartlarına Recep Tayyip Erdoğan parkının sahip olduğu görülmüştür. Parkın düşük puan almasına güvenlik hissinin olmaması, bisiklet kullanımı için uygunsuzluğu, görsel etkisinin zayıflığı göstergeleri en fazla etkili olmuştur. Recep Tayyip Erdoğan Parkı'nda bitkisel tasarım oldukça zayıftır. Yaya, bisiklet yolu sirkülasyonuna yer verilmemiştir. Park oldukça bakımsız, donatıları yetersiz durumdadır. Bu park peyzajın kalite kriterlerini sağlayacak birçok özellik bulunmamaktadır. Nitekim [1]'in de belirttiği gibi gövenlik, ulaşılabilirlik, bakım gibi faktörler kent parklarının kalite kriterlerini oluşturmaktadır.

Erzurum kent parkları peyzaj kalite göstergelerine göre değerlendirildiğinde en yüksek puanı ulaşılabilirlik göstergesinden almışlardır. Araştırmaya konu olan parkların hepsi aktif olarak kullanılan ana yol hattı üzerinde kurulmuştur. 
Araştırmadan elde edilen sonuçlara dayanarak Erzurum'daki kent parkları için sunulan öneriler aşağıdaki gibidir;

> Kent parkları bütüncül bir mekânsal planlama ve tasarım sürecinin parçası olarak ele alınmalıdır.

> Yerel yönetimlerin kent parkı tasarım ve uygulama süreçlerini bölge ve Erzurum kent koşullarını uzun süreden beri bilen ve değerlendiren uzmanlar ve akademisyenler ile yürütmesi ve kullanıcıların talep ve beklentilerini bir arama konferansı süreci ile belirlemesi beklenmektedir.

$>$ Her bir park için özellikle sınırlama, tanımlanmış bir giriş, bitkisel ve kentsel donatı elemanları bakımından eksikliklerin giderilmesi beklenmektedir.

$>$ Kent parklarının güvenlik, bakım ve yönetim süreçleri için bir izleme değerlendirme süreci yürütmesi beklenmektedir.

Drzurum kentinde parklar birbirinden bağımsız ve ilişkisiz olarak uygulanmaktadır. Kent içi yeşil altyapı politikası geliştirme sürecinin bir parçası olarak kent parklarının ulaşım sistemleri ve kentin açık-yeşil alanları ile kesintisiz ekolojik koridor olarak bağlanmasına yönelik süreçler desteklenmelidir.

Sonuç olarak, kent parklarının kalite göstergelerinden farklı aktivite olanakları, parkın bakımlı olması, güvenlik hissi, bitkisel tasarım, donatı elemanlarının yeterli olması, ulaşılabilirlik, engellilere uygun tasarım, park içi yaya yolları, bisiklet yolları gibi tüm faktörlerin eksiksiz olması parkın kalite standartlarını yükseltmekte, tercih edilebilirliğini sağlamaktadır.

\section{Kaynaklar}

[1] Yücel G.F., Yıldızcı A.C., “Kent Parkları İle İlgili Kalite Kriterlerinin Oluşturulması”, İtüdergisi/a (Mimarlık, planlama, tasarım, 5(2, 2): 222-232, 2006

[2] Polat A.T., Önder S., “Kent Parkı Kavramı ve Konya Kenti İçin Bir Kent Parkı Örneği”, S.Ü. Ziraat Fakültesi Dergisi, 18 (34): 76-86, 2004

[3] Chiesura A., "The Role Of Urban Parks for the Sustainable City”. Landscape and Urban Planning, 68(1): 129-138, 2004

[4] Emür S.H., Onsekiz D., "Kentsel Yaşam Kalitesi Bileşenleri Arasında Açık Ve Yeşil Alanların ÖnemiKayseri/Kocasinan İlçesi Park Alanları Analizi”, Sosyal Bilimler Enstitüsü Dergisi, 22(1): 367-396, 2007

[5] Çakçı I., Çelem H., "Kent Parklarında Görsel Peyzaj Algısının Değerlendirilmesi”, Tarım Bilimleri Dergisi, 15(1): 88-95, 2009

[6] Bektaş A. "Bursa İli Kent Parklarının, Reşat Oyal Kültürparkı, Soğanlı Botanik Park1 Ve Merinos Park1 Örneklerinde Peyzaj Tasarım Kriterlerine Göre İncelenmesi”. Selçuk Üniversitesi, Fen Bilimleri Enstitüsü Yüksek Lisans Tezi, 159s, Konya, 2010.

[7] Bekçi B., Taşkan G., “Açık Yeşil Alanlardaki Kent Donatılarının Kişisel Mekan Uzaklığına Etkisi: Bartın Kenti Örneği”, Bartın Orman Fakültesi Dergisi, 22: 61-71, 2012

[8] Alpay C.O, Kalaycı, A., Birişçi T., “Ekolojik Tasarım Kriterlerine Göre Kent Parkı İyileştirme Modeli: İzmir Kültürpark Örneği”, TMMOB 2. İzmir Kent Sempozyumu, 28-30 Kasım, İzmir, 2013

[9] Özdemir B., “Konya İlinde Bulunan Bazı Kent Parklarının Kullanıcı Tercihleri Açısından Değerlendirilmesi”, Selçuk Üniversitesi, Fen Bilimleri Enstitüsü, Yüksek Lisans Tezi, 81s, Konya, 2013. 
[10] Şişman E.E., Gültürk P., Tekirdağ Kent Merkezinde Bulunan Parkların Mevcut Durumunun Belirlenmesi ve Öneri Bir Peyzaj Projesinin Hazırlanması. Tekirdă Ziraat Fakültesi Dergisi, 11(2): 98-109, 2014

[11]Zhang S., Zhou W., "Recreational Visits to Urban Parks and Factors Affecting Park Visits: Evidence from Geotagged Social Media Data”, Landscape and Urban Planning, 180: 27-35, 2018

[12]Bonnie K.L.M., Jim C.Y., "Linking Park Users' Socio-Demographic Characteristics and Visit-Related Preferences to İmprove Urban Parks”, Cities, 92: 97-111, 2019

[13]Çınar İ., “Kent Parklarının Rekreasyonel Yönden Yeterlilikleri Üzerine Fethiye-Muğla Kent Parkları Örneğinde Bir Araştırma”. ADÜ Ziraat Fakültesi Dergisi, 5(2):33-38, 2008

[14]Elinç H., “Görsel Kalite Değerlendirmesi Yöntemi İle Antalya İli Alanya İlçesindeki Abdurrahman Alaettinoğlu ve Alanya Belediye Başkanları Kent Parklarının İrdelenmesi”, Selçuk Üniversitesi, Fen Bilimleri Enstitüsü, Yüksek Lisans Tezi, 129s, Konya, 2011.

[15] Erdoğan R., Oktay H.E., Yıldırım C., “Antalya-Konyaaltı Parklarında Kullanılan Donatı Elemanları Tasarımlarının Kullanıcı Görüşleri Doğrultusunda Değerlendirilmesi”, Artvin Çoruh Üniversitesi Orman Fakültesi Dergisi, 12 (1):1-8, 2011.

[16] Polat A.T., "Kent Parklarında Görsel Kalite ve Doğallık Derecesi Arasındaki İlişkilerin Belirlenmesi”, Ĭgdır Üniversitesi Fen Bilimleri Enstitüsü Dergisi, 2(3): 85-92, 2012

[17] Kaypak Ş., “Antakya’nın Kent Kimliği Açısından İrdelenmesi”, Mustafa Kemal Üniversitesi Sosyal Bilimler Enstitüsü Dergisi, 7: 373-392, 2010

\section{Extended Abstract}

\section{Introduction}

Urban life creates social, sociological, economic and psychological pressures on people. Urban spaces structural density, traffic load, pollution and so on. factors are under pressure. Green areas in cities have the effect of improving the negative conditions of living in the city. City parks play a major role in improving the quality of life of the city. The quality of urban parks depends on the success of planning, design, implementation and maintenance conditions.

One of the important components of urban green areas is the parks. In order for the parks to be more functional and aesthetic, they should be designed considering the landscape quality indicators. Many features such as the accessibility, vegetative design, reliability, richness and quality of the reinforcement elements of a park make it more preferred by users. The aim of this research is to evaluate the landscape quality indicators in urban parks; Olympic Park, 100th Park, Tavsanli Park, Recep Tayyip Erdogan Park, National Garden, Martyrs' Park, Palandoken Family Tea Garden are among the important parks in Erzurum.

\section{Method}

In the parks of the research area, video and photo shoots were made and 20-person expert groups were evaluated by means of a 5-point Likert Scale to evaluate the visual impact, structural design, plant design and flooring quality indicators. In determining quality criteria; landscape quality indicators of the 7 most commonly used parks in Erzurum were evaluated by landscape architects with postgraduate degree (master and/or doctorate).

\section{Results and Discussion}

According to expert evaluation in this research carried out with the aim of determining landscape quality indicators of some important parks in Erzurum; Olympic Park has the highest quality. The most important indicator affecting the quality of the Olympic Park is that it has different activity opportunities. The Olympic Park has come to the forefront with its functions appealing to all age groups that Erzurum people demand in the summer season. Picnic areas, sports areas, children's playgrounds, water-based recreation facilities, cafes, indoor social facilities, walking paths, bicycle paths, wedding hall is a large area with many activities such as established. The intensity of such activity areas allows more socialization of the users coming to the park.

According to the expert opinions of the second garden of the National Garden; accessibility, park maintenance and cleaning quality indicators. The park, which was built by Erzurum Metropolitan Municipality where Aziziye Monument is located, attracts attention with its new landscape design. Bicycle and walking paths, seating areas, playground, giant 
chess area and mini ornamental pool are preferred with its suitability for disabled design. Aziziye Monument has given identity to the park. Aziziye monument is a work that tells the history of Erzurum city.

As a result of the research, Recep Tayyip Erdoğan park has the lowest quality standards. The lack of a sense of safety, unsuitability for cycling, and poor visual impact were the most effective factors for the low score of the park. The plant design in Recep Tayyip Erdoğan Park is very weak. Pedestrian and bicycle path circulation is not included. The park is quite neglected, the equipment is insufficient. There are not many features that will meet the quality criteria of this park landscape.

Based on the results of the research, the recommendations for urban parks in Erzurum are as follows, urban parks should be considered as part of an integrated spatial planning and design process; local governments are expected to carry out the design and implementation of the city park with experts and academicians who have long known and evaluated the region and Erzurum city conditions and determine the demands and expectations of the users through a search conference process; for each park, it is expected to overcome the shortcomings, especially in terms of limitations, a defined entrance, vegetal and urban reinforcement elements; city parks are expected to carry out a monitoring and evaluation process for the safety, maintenance and management processes; in the city of Erzurum, parks are implemented independently and unrelated. As part of the development process of urban green infrastructure policy, the processes of linking urban parks with the transportation systems and open-green areas of the city as a continuous ecological corridor should be supported.

As a result, different possibilities of activity from the quality indicators of urban parks, the well-maintained park, the feeling of security, vegetative design, sufficient equipment, accessibility, design suitable for disabled people, all the factors such as pedestrian paths in the park, bicycle paths are complete and the quality standards of the park are increased. 